\title{
Citizenship, National Identity, and Nation-Building in Azerbaijan: Between the Legacy of the Past and the Spirit of Independence
}

\author{
Ayça Ergun* (10 \\ Middle East Technical University, Üniversiteler Mahallesi, Ankara, Turkey \\ ${ }^{\star}$ Corresponding author. Email: ayer@metu.edu.tr
}

\begin{abstract}
The aim of this article is to shed light on the process of nation-building and the formation of national identity in post-Soviet Azerbaijan. The peculiarity of Azerbaijani nation-building is that the debates on how to build a nation and define national identity were nourished by two discourses: Azerbaijanism (Azerbaycançılıq) and Turkism (Türkçülük). The article focuses firstly on the discourses on national identity and nationbuilding in the pre-independence period while elaborating on the roots and premises of the nationalist independence movement. Secondly, it highlights the discourses of nation-building in the post-independence period while discussing the meanings attributed to national identity and nationhood. It shows how these two discourses shaped the existing identity formation in Azerbaijan with a particular emphasis on citizenship identity, marked by multiculturalism, hospitality, tolerance, and patriotism. Yet one can still categorize the country as having an incomplete nation-building process, due the violation of territorial integrity as a result of the Karabakh conflict.
\end{abstract}

Keywords: Azerbaijan; nationalism; national identity; citizenship

\section{Introduction}

The study of the rise of nationalism in the Soviet Union and how national resurgence paved the way for its dissolution is the subject of a wide range of academic literature (Bremmer and Taras 1997; Brubaker 1996; Buttino 1993; Diuk and Karatnycky 1993; Hajda and Beissinger 1990; Lapidus, Zaslavsky, and Goldman 1992; Smith et al. 1998; Tishkov 1997). The process was generally explained by the legacy of the Soviet Union, the emergence of nationalizing elites and their rediscovery of cultural, social, political, and national origins, and by the ways in which the nationalist-independence movements paved the way for the formation of independent states. The question of how far national resurgence was the natural consequence of glasnost and perestroika was one point of inquiry. Some authors argued that it was the result of the suppression of the national and religious identities that were kept under control by Soviet ideology in creating Soviet citizens, whereas others authors argued that it was the Soviet policy toward the titular nationalities that defined the current boundaries of identity formation (Brubaker 1996; Suny 1990; Saroyan 1989). Zaslavsky stated that the definition of ethnicity on the basis of predefined "ethnoterritorial units" created institutionalization "on the individual level through the introduction of a comprehensive internal passport which immutably fixed the ethnic affiliation of every Soviet citizen" $(1992,99)$. Instead of eliminating national affiliations, Soviet nationality policy unconsciously created and consolidated ethnicity and the "growing cohesion among the major

\footnotetext{
(C) The Author(s), 2021. Published by Cambridge University Press on behalf of Association for the Study of Nationalities. This is an Open Access article, distributed under the terms of the Creative Commons Attribution licence (http://creativecommons.org/licenses/by/4.0/), which permits unrestricted re-use, distribution, and reproduction in any medium, provided the original work is properly cited.
} 
nationalities" (Suny 1990, 6). It was this policy which provided the "reconstruction of [an] ethnic identity that embraces the nation as a whole" (Saroyan 1989, 220). The project of nation-building in the post-Soviet era then is marked by the remembrance of history, the formation of national identity on the basis of ethnicity and religion, and following the construction of nationhood, redefinition and reinterpretation of national identities.

This article sheds light on the nature of the process of nation-building and the formation of national and citizenship identities in post-Soviet Azerbaijan. It problematizes two main discourses, Azerbaijanism and Turkism, which offer different yet complementary notions of national identities. While doing this, it provides an analysis on how they were interpreted by the political and intellectual elite in order to show how they are incorporated and articulated to the process of nation-building. The first part primarily covers the pre-independence period while elaborating on the roots and premises of the nationalist independence movement in Azerbaijan, in order to provide a historical background to understand different conceptualizations of national identity in the postSoviet period. It illustrates how the independence movement, together with collective action, shaped the relationship between nation-building, state-building, and democratization. The second section focuses on the discourses of nation-building in the post-independence period. In this part, the meanings attributed to nationhood and national identity will be discussed with reference to Ebulfez Elchibey's, Heydar Aliyev's, and Ilham Aliyev's governments. In the third part, I focus on how external actors, namely, Iran, the Russian Federation, and Turkey, inform the perceptions of national identity in order to show to what extent ethnic, linguistic, and religious ties played a role. Finally, I discuss the role of the Karabakh conflict due to its significance for both Azerbaijanism and Turkism, since it constitutes the main challenge in the process of nation-building.

Early and recent works on national identity, nationalism, and nation-building in Azerbaijan lucidly provide an analysis of the sources of national identity formation in Azerbaijan from a historical perspective (Altstadt 1988, 1992, 2017; Swietochowski 1994a, 1995, 1999; Y1lmaz 2013; Hatcher 2008). Both Altstadt and Swietochowski identified the Turkish, Persian, and Russian influences in shaping the meanings attributed to national identity, focusing on Russian colonial rule, the first republic period between 1918 and 1920, Soviet rule, and the pre-independence and early independence periods. More recent works identified different aspects of national identity formation and nation-building, focusing on the construction of Azerbaijani identity (Cornell 2011; Ismayilov 2012; Siroky and Mahmudlu 2016; Mahmudlu 2017); issues related to the citizenship (Tabachnick 2019); the relationship between national identity and religion (Cornell, Karaveli, and Agajanov 2016; Ergun and Çitak 2020; Valiyev 2005); gender and identity (Heyat 2006; Tohidi 1997); how political parties engage in nationalism as an ideology (Altstadt 2017; Guliyev 2019; Sultanova 2014); and the impact of the Karabakh conflict (Broers 2019; De Waal 2013; Zürcher 2007; Garagozov 2012; Uzer 2012). The peculiarity of Azerbaijani nation-building is that the debates on how to build a nation and define national identity had been nourished by two discourses: Azerbaijanism (Azerbaycançılıq) and Turkism (Türkçülük). Most, if not all, analyses present them as discourses of two different political groups, that is, government and opposition, representing alternatives to each other. This article argues for the complementarity of these two discourses, analyzing their interrelationship and how this interrelationship and complementarity influence the perceptions of national identity in Azerbaijan.

In the post-Soviet period, the Popular Front of Azerbaijan (PFA), under the leadership of Ebulfez Elchibey, propagated for Turkism, whereas Heydar Aliyev's government was in favor of Azerbaijanism. In 1988, the eve of the dissolution of the former Soviet Union, the PFA was established. A group of nationalist intellectuals transformed a discussion group to a mass movement asking for independence. Nationalist ideology together with social mobilization and collective action created a sense of awareness of ethnic origins and national consciousness and redefined the bonds of solidarity. It was not a nationalist ideology that forced people to participate in demonstrations, rallies, and meetings; rather, it was within the movement, through collective action, that the whole issue of national identity was reformulated and the idea of belonging to a nation emerged beyond 
the established boundaries of clan, family, and region. The Popular Front Government (PFG), which came to power in 1992, articulated this nationalist discourse framed with the idea of Turkism and emphasized the Turkish origins of the Azerbaijani nation underlying pre-Soviet ethnic and cultural heritage. After Heydar Aliyev's coming to power in 1993, emphasis in nation-building shifted to Azerbaijanism, an ideology thought to ease ethnic tensions within the country and an interpretation of identity that had its roots in the Soviet period, which facilitated its internalization. Ilham Aliyev's period is marked by the consolidation of Azerbaijani citizenship identity. Since 2003 the consolidated notion of Azerbaijanism provided a basis for a civic understanding of Azerbaijanism and inclusionary citizenship identity. Yet, awareness of the Turkish roots has also increased compared to the early years of independence. The popularity of the Turkish origins does not at all challenge Azerbaijani identity. It rather remains complementary and creates a peaceful coexistence. In this existing interpretation the idea of independence is highly valued; building up a new state became a source of pride; Turkish roots are underlined, and a new understanding of citizenship has been updated and advertised. The ethnic roots are not promoted, yet are contained at very core of the Azerbaijani citizenship identity. This idea of Azerbaijani citizenship predominantly refers to multiculturalism, tolerance, and secularism, and these are promoted at the international milieus. All have a very strong background in Azerbaijani society both in preSoviet and Soviet times. They are historically embraced and promoted by the political and intellectual elite of Azerbaijan.

As of 2020, Azerbaijani identity embraces the attributes of Azerbaijanism and Turkism. Both ideologies, which were represented by differing political camps, are complementary rather than contradicting. The emphasis on multiculturalism and tolerance has been particularly incorporated by the ruling elite. Early interpretation was a mere repetition and rearticulation of identity $a$ la the Soviet Union, emphasizing peaceful coexistence of the majority and minorities, whereas in its current interpretation, a new form of patriotism has been integrated. In this new interpretation the issue of national identity is not fully referring to the ethnic identity but rather to being proud of state existence, consolidation of sovereignty, remembrance of the early independent-state tradition, and the heritage of the Azerbaijan Democratic Republic (ADR). Additionally, the visibility of Azerbaijan as a country and Azerbaijaniness, with all its social and cultural attributes, have become an integral part of the internationalization of the country's image. Hosting international events such as the Eurovision Song Contest, the European Games, Formula One, and Islamic Olympic Games can be seen as part of new national branding, but they can also be interpreted as examples of this new understanding and practice.

The article is based on data collected through 125 in-depth interviews. The fieldwork was conducted in Azerbaijan during November-December 1996; August 1998; April-July 2000; October-November 2002; June 2004; June-July 2014; February 2015; November-December 2016; April 2017; and September 2019. Respondents include politicians, members of parliament (from 1995 to 2015), representatives of civil society organizations, journalists, experts, and scholars. They either represent or support different political parties; however, there is also a significant number of respondents who do not associate themselves either with the government or the opposition. Thus, the analysis reflects on the views of representatives of different political spectrums. The expert interviews were conducted with scholars who work and write on issues related to national identity in Azerbaijan. The respondents were asked questions related to perceptions of national identity, attributes of nation- and state-building, interpretations of Azerbaijaniness and Turkishness, and problems in or challenges of the consolidation of national identity.

\section{From Freedom Square to the Popular Front of Azerbaijan: The Rise of a Nation}

The years preceding and succeeding independence in the South Caucasus were turbulent. They were marked not only by an attempt to restore cultural, political, and economic sovereignty but also by interethnic conflicts and the wars between countries, such as the case of Nagorno-Karabakh. The 
independence movements and mass mobilization were handled by the newly formed nationalist counter-elite that constituted an alternative to the existing power structure, that of the Communist Party. The road to independence was marked by the establishment of movements, popular fronts, and committees whose initiatives led to declarations of sovereignty and then of independence.

Nationalism in post-Soviet Azerbaijan evolved in three phases, serving first as a tool for defense, secondly as a tool for state-building, and finally as a tool for democratization. Karabakh problem constituted a major stimulus for the emergence of the nationalist independence movement. The Azerbaijani nationalist movement emerged via the definition of external enemies, that is, Armenians and Russians, which simultaneously paved the way for the nationalist upheavals as a defense movement.

The defeat in the war, the loss of territory, and the will to regain it permeated the whole discourse of national ideology and became the main motive of the independence movement. In this defense phase, the first component of the independence movement was the expression of ethnic identity as the main signifier of the formation of a national identity, the assertion of which was forbidden in the Soviet period. It was realized under the slogans of "being proud of history" and "self-awareness," by glorifying national cultures and history, and by mystifying national heroes and glories. One of the representatives of the PFA elite commented, "What makes us nationalists? We wanted to see our country independent. We emphasized the fact that we are a part of the Turkish nation, and we struggled not to forget national identity. We fought for our national identity and national culture. That is why we are nationalists." "The idea of nationalism in this phase can be basically characterized by loving the nation, preserving the ethnic and cultural values, the establishment of statehood, the rediscovery of ethnic, cultural and social origins and the improvement of the national heritage. ${ }^{2}$

The second component of the movement and formation of the PFA was the rediscovery of the nation on the basis of a redefinition and reconceptualization of national identity. The first sign of a revival of national identity was the Freedom Square Movement (Meydan Harekat1), which occurred as a result of the Nagorno-Karabakh conflict challenging territorial integrity. In February 1988 the Armenians of the Nagorno Karabakh Autonomous Oblast (NKAO) asked for the annexation of the oblast to the Armenian SSR in accordance with the principles of self-determination. On February 12,1988 , the first mass meeting at Xankendi, the capital of the NKAO (Stepanakert in Armenian) took place. On February 21, the people's deputies asked for the unification of the NagornoKarabakh with the Armenian SSR and requested the agreement of the Supreme Soviets of Azerbaijan and Armenia. The demands were followed by meetings in Erevan and Stepanakert. As a result, in the small industrial town of Azerbaijan, Sumgait, near Baku, clashes between the two ethnic groups took place on February 28, 1988, during which 32 Armenians and 26 Azerbaijanis were killed. The Sumgait event was interpreted as a pogrom (Abrahamian 2001, 130; Chorbajian 2000, 2) or massacre (Papazian 2001, 84) by the Armenians and was used as a means of justification for their demands (Balayev and Mirze 2000). For Azerbaijanis, on the other hand, the event was the result of agitation and provocation of both Armenians and Russians during which the local authorities consciously did not take the necessary steps in order to prevent the conflict (Balayev and Mirze 2000, 18).

On May 18, 1988, the first meeting in Azerbaijan took place protesting the indecisiveness of the local Communist Party and asking for the territorial integrity of the country (Balayev and Mirze 2000, 12). The first secretary, Kamuran Bagirov, was replaced by a new Moscow appointee, Abdurrahman Vezirov. Following the replacement, the Armenian Supreme Soviet passed a resolution asking for the transfer of the NKAO (Altstadt 1992, 197). The Azerbaijani Supreme Soviet considered this as unacceptable and asked for respect for the territorial integrity of Azerbaijan (Balayev and Mirze 2000, 18). On November 12, 1988, the Presidium of the USSR Supreme Soviet decided to retain the NKAO in Azerbaijan (Altstadt 1992, 199). This was followed by the first organized mass meeting from which the movement would grow. It took place in the main square of Baku, named Lenin Square, which would soon be called Freedom Square. 
Between the November 17 and December 5, 1988, first hundreds then thousands of people gathered at Freedom Square for days and nights to protest against the Armenian demands and the reluctance to act by the Communist Party of Azerbaijan (Tahirzade 1997). It is also argued that this was a reaction against "growing social problems and injustice" (Balayev and Mirze 2000, 14). On December 5, 1988, the eighteen days' meeting was split up by the special security forces. A state of emergency was implemented. The commencement date of these meetings, November 17, is now celebrated as a national day called the National Resurgence, after the dissolution, and has acquired symbolic importance.

The Meydan, which was the first sign of the formation of political-organizational activity, has had historical significance for the process of political transformation and democratization. Moreover, the movement, characterized as "a broad based, multi-issue" one (Altstadt 1992, 200) paved the way to the formation of a collective identity, which was defined in national terms, even though the national referred to a vague conception of identity in the sense that the symbols of the national were unknown. A historian who actively took part in the meetings said,

There were many flags at the meetings. The green flag, the Turkish flag, the Azerbaijani SSR flag... We thought that we needed our real flag. ${ }^{3}$ Nobody knew what it looked like. I remembered that I saw it in the Handbook of Azerbaijan, in an archive when I was a graduate student in Moscow. I remembered the colors, red, green, and blue, but not the order. But nobody really knew the order or the shape of the star. We went to the shop, we bought the tissues and a lady made it in one night. The day after that was the first time that the flag of Azerbaijan was raised in the Meydan. ${ }^{4}$

In this respect, the first revival of national memories and the resurrection of national symbols took place at the Meydan. Meydan was the milieu that constituted an opportunity structure for national identity to emerge and be expressed. The Karabakh conflict was the main stimulus for the remembrance of not only Turkish origins but also revealing of the historical signifiers of a once built-up nation and state that was the Azerbaijani Democratic Republic of the early 20th century (1918-1920). The views of the ADR's intellectual and political elite provided a source of inspiration for the PFA not only in terms of ideological tenets but also as encouragement. They considered the ADR's experience as a source of pride (Ergun and Çitak 2020), providing them with the ability and power to rebuild yet another republic. One of the former members of the PFA and a high-ranked official argued, "At Meydan, we felt like 'We did it once, we can do it again.' "5 The idea of Turkism constituted the core of the ADR's elite's vision on national identity (Lemercier-Quelquejay 1984; Altstadt 1986; Swietochowski 1995). In his work entitled Asrımızın Siyavuş'u, Mehmed Emin Resulzade discusses the different impacts on the Azerbaijani identity, including Iranian, Turkish, Russian, Muslim, and Christian, concluding that “Azerbaijanis are Turks" $(1989,67)$. One of the participants of the movement stated that it was by then he felt like a "real citizen in his own state for the first time in his life." ${ }^{6}$ With popular support and with revealed issues of the Freedom Square Movement, from 1989 onward the PFA prepared the ideological and conceptual base of the nationbuilding agenda.

\section{The Popular Front of Azerbaijan and Its Nation-Building Discourse}

The PFA's nation-building agenda was set on the basis of three important and complementary perceptions about nationhood that affected the ways in which discourses on national identity were formed. These perceptions referred (1) to nationhood in the past; (2) to nationhood within the territory; and (3) to nationhood beyond the boundaries. Here, nationhood in the past refers to the revelation of history, remembrance of cultural, ethnic, and religious origins and their assertions. Nationhood within the territory means protection of the land, inviolability of the frontiers, and preservation of territorial integrity. Nationhood beyond the boundaries has two dimensions. 
The first dimension foresees collaboration with and extension of the relationships with other Turkic peoples of the Soviet Union, mainly in Central Asia due to the linguistic, ethnic, cultural, and religious affinities. The second dimension is related to Azerbaijanis living outside the current boundaries, primarily those living in Iran. With reference to these perceptions, four main issues were addressed in the PFA's programs: Soviet policies toward nationalities; relations with other Turkic peoples within the USSR; the relationship between Azerbaijani people and national ethnic minorities; and the restoration of the first democratic republic's heritage.

In terms of nationhood in the past, the first declaration of the PFA emphasized the right to selfdetermination of nationalities, and it was argued that the "current USSR rule does not create favorable legal and socioeconomic conditions in the USSR to determine freely the right of selfdetermination of nationalities" (Nerimanoglu 1992, 85). As for the reference to the national revival and rediscovery of past origins (Akiner 1997), it stated that "the symbols of the Azerbaijani Democratic Republic (three color flag, national anthem, symbol) should be recognized as the national symbols of the republic" (Nerimanoglu 1992, 89-90). The revitalization of national memory plays a significant role in state-building as well. Rediscovery of the previous state tradition rather than creation or invention made the elite feel more secure and allowed them to think that they already had a solid basis for future statehood. In this respect, the pre-Soviet experience would not constitute a basis for new state-building but served as an "invention of tradition" (Hobsbawm 1983 ) in the early years of independence and as a source of inspiration and pride in its later stage with Azerbaijan's being the "first secular parliamentary democracy in the Muslim world."

Nationhood within the territory was defined in terms of majority and minority relations. The PFA's program emphasized "the termination of the autonomous status of Nagorno-Karabakh and the full implementation of the sovereign rights of Azerbaijan over the territory" (Nerimanoglu $1992,91)$. In terms of relations with other nationalities, it noted, "The relationship between the people of Azerbaijan and other minorities, who are less numerous, should be established in accordance to both sides' rights and will" (98). The program also entailed the right of preservation and development of national cultures and expressed its will for greater cultural autonomy. It was stated that "the PFA owes the creation of conditions which favor the protection and empowerment of culture, language, and national traditions of Russians, Jews, Talyshs, Armenians, Georgians, Kurds, Lezgins, and other national minorities in the Azerbaijan's SSR" (110). Such conception of majority-minority relations constituted the basis of the nationalists' discourse on Azerbaijanism. Although Elcibey's government has been blamed of being Panturkist and for using discriminatory and exclusionary discourse, it later became apparent that the newly emerging elite would like to restore the right of the majority to name its identity without necessarily discriminating against the national minorities. The presidential decree accepted in 1992, which is still in force, is an example of this attitude.

In terms of nationhood beyond the territory, the PFA "invites all Turkic peoples of the USSR to resist and to collaborate," while noting that all Turkic peoples "lost their traditions of state administration, ... were denied the experience of statehood" (92), "oppressed by exiles, deportations and killings ... were regarded as a cheap labor force, source of raw materials and market" (94-95). It gave special importance to the improvement of relationships with the Azerbaijanis living in Iran, while emphasizing the development of relationships respectful to the territorial integrity of the USSR and Iran and to the principles of "inviolability of the borders of the Azerbaijan SSR and Iran” (101). In its first program, Azerbaijan SSR's political, cultural, and economic sovereignty would entail remaining within the USSR (102), whereas in 1991 the idea of independence became obvious. Yet, the simultaneous attempt for the democratization of society and the redefinition of nationhood hindered the implementation of the suggested aims. Elchibey noted, "Our struggle is a struggle of democracy and national unity. The movement for democracy overlaps with the national independence movement. That is why we are suffering now, falling to left and then to right" (1992, 81-82). In this sense, the PFA as a movement created a framework for post-Soviet transformation where the issues of how to be a democratic country, how to construct the state, and how to form a 
nation intertwined, not necessarily contradicting each other. It can be argued that particularly after Ilham Aliyev's coming to power the close association between nationalism and democracy lost its values. The oppositional activity concentrated more on the further democratization rather than discussing the premises of the national identity. Due to apparent decline of the opposition in the political domain, nationalism is largely associated with so-called defeated democrats. Nationalism lost its priority status within the discourse, and language of political struggle and appeals for democratization became the major priority, particularly after death of Ebulfez Elchibey in 2000. In other words, nationalism as a movement and Turkism as a discourse lost their owners in the political domain. Yet the later years of political transformation shows that Turkishness was incorporated into the definition of national identity and actually became an integral part of the citizenship identity. In the PFA years Turkishness was to be remembered and reminded to those who lost the sense of their ethnic origins in the Soviet period. The experience of 29 years of independent statehood not only reestablished but also consolidated Azerbaijani citizenship identity. Within this Azerbaijani citizenship identity, there is now a more conscious and increased awareness on the Turkish roots and a peaceful coexistence rather than a tension.

\section{Post-independence Nationalism as a Tool for State-Building and Democratization}

In the early post-Soviet period, the nation-building process in Azerbaijan has been nourished by two discourses represented by government and opposition: Azerbaijanism and Turkism. Debate over national identity provided an arena of elite contestation on state-building and nationbuilding. These two discourses are not necessarily contradictory and in some sense are complementary, but their emphases on how and on which basis to build a nation are quite different. The Popular Front Government's discourse, under the presidency of Elchibey, centered on the rediscovery of Turkish identity; Aliyev's regime took for granted the perception under the Soviet rule and reconsolidated the term Azerbaijani as the name of the national identity. Azerbaijani as the name of identity did not encounter much resistance and was internalized. However, it is noteworthy to look at the contents of both discourses in order to understand the roots of contemporary perceptions and conceptualizations of national identity. As of 2020 the citizenship is more associated with the idea of independent statehood, glorifying the value of independence, and the territorial integrity of the country. ${ }^{8}$ The respondents whom I interviewed between 1996 and 1998 mainly conceptualized the national identity with reference to the discourses of Azerbaijanism and Turkism. Although these two discourses were represented by two opposing political groups, proponents of Turkish identity did not reject the Azerbaijani identity as citizenship identity and proponents of Azerbaijanism did not undermine or reject the Turkish origins. Recent interviews conducted between 2017 and 2019 with a younger generation of intellectual elites showed that the perceptions about national identity underline "the Azerbaijani identity with Turkish origins" with a strong and frequent statements including "being proud of living in an independent country," "Azerbaijan determines its own faith and path," "Azerbaijan alone can determine its own priorities," and "We worked hard to consolidate our independence. This is our major security concern." Through recognition of Turkish origins, inserted Turkishness is replaced by a well-informed sense of national identity that resulted in the formation of peaceful coexistence of Azerbaijanism and Turkism.

Nationalism (with its emphasis on Turkism) served as a tool for state-building and for creating a state ideology under the PFG. With Aliyev's coming to power in 1993, the emphasis was shifted to Azerbaijanism and to stability in order to protect statehood. Not only is the changing emphasis remarkable. With the overthrow of the PFG in 1993, the nationalist discourse of the opposition became an integral part of the democratization agenda rather than the nation-building and statebuilding agendas. "Being nationalist" and "being democratic" became synonymous and were used interchangeably. In other words, the opposition embodied both being a nationalist and being a democrat in its struggle against the regime in the early years of independence. 


\section{The Popular Front Government and Its Nation-Building Agenda}

The rule of the PFG is crucial in terms of nation-building and state-building. Since the first mission (i.e., the achievement of independence) was completed, nationalism as a defense movement converted into nationalism as a tool for state-building. The issue of national identity that was the stimulus of the demand for independence and democracy became a tool for statebuilding. The agenda of state-building was proclaimed to be based on democracy, secularism, and the rule of law. The Front's agenda for post-Soviet political transformation denounced all that was Soviet in an attempt to "correct the errors of the past" (Goltz 1998, 256). The alphabet was changed from Cyrillic to Latin, and the government encouraged the use of the Latin alphabet and the Azerbaijani language in all state affairs. The new currency manat, considered a main marker of independent statehood by President Elchibey, was introduced instead of the ruble (Elchibey 1998, 18). It became fashionable to change the family name from Russian names to Azerbaijani ones. While changing the names, they drop the Russian patronymic ov or ova (son of) from the family name in favor of the Azerbaijani equivalents, oglu, zade, or $l i$, or just dropped the patronymic altogether (Goltz 1998, 256).

The nation-building agenda of the PFG was a substantive change for national identity formation and state-building. Its significance was visible in the naming of the national identity and the language. The PFG conceptualized nationhood in terms of majority and minority relations, which would consequently lead to a contested debate because such a distinction could create disturbances between the majority and national minorities and lead to the possible practices of discrimination. Apparently strong emphasis on the Turkish dimension of national identity provoked some separatist movements, such as the Lezgins and Talyshs in 1993 and 1994.

The national ideology was defined on the basis of Turkism, modernization, and Islam (Tahirzade 1999, 140). ${ }^{10}$ Elchibey emphasized the fact that this Turkism was not linked to the ideas of chauvinism as "it is the necessity of being conscious of one's history, civilization, and himself a Turk" (150). It was this national ideology, which was representative of the majority of the people, namely, Turks that would eventually initiate the establishment of democratic statehood. ${ }^{11}$ The presidential decree entitled "The Presidential Decree on the Official Language of the Republic of Azerbaijan," adopted December 22, 1992, complemented this view. The decree states that "the official language of the Azerbaijan Republic is Turkish" (Azerbaycan 1992b). The majority of the population was called Azerbaijani Turks or Turks. Thus, the Front restored the name of the people, which had changed in 1937 from Turks to Azerbaijanis. ${ }^{12}$

In fact, the nationhood policy of the PFG defined two main identities within Azerbaijani citizenship: the majority and the minorities. The same decree says, "All the citizens of the Republic of Azerbaijan are guaranteed the freedom of choosing their educational language. The national ethnic minorities living in Azerbaijan are entitled to have separate classes in their native language in preschooling, primary and secondary schools" (Azerbaycan 1992b, art. 3). In order to implement this law, the PFG began to publish new textbooks in Azerbaijani Turkish and in the minority languages (Tahirzade 1999, 49). Protection of the rights of ethnic and religious minorities was also one of the main concerns of the PFG. Another presidential decree, entitled "The Presidential Decree on the Protection of the Rights and Liberties of National Minorities, Less Populated and Ethnic Groups and State Assistance for the Development of their Language and Civilisation" was adopted in 1992 on the status of ethnic and religious minorities (Azerbaycan 1992a). This was presented as the main proof of their nondiscriminating discourse. Elchibey argued, "How could we be intolerant and not respectful of the rights of the ethnic minorities living in Azerbaijan? After being subjects of the discriminatory policies of the Soviet power, we are the last ones who could violate their rights." 13 The law ensures "the principle of equality for all citizens regardless of their nationality, ethnic origins and religion," as well as "the protection and the development of the indigenous culture, language and religion of national minorities and ethnic groups" (Azerbaycan 1992b, art. 2). Additionally, funds were allocated from the state budget for cultural civilizational centers of ethnic 
minorities and religious minorities. After Aliyev's coming to power in 1993, the PFG elite became the main opposition of the country and established a few political parties, namely, the Azerbaijan Popular Front Party, the Musavat Party, and the Azerbaijan Nationalist Independence Party. Their discourses on nationalism, national identity, and nation-building were overlapping to a great extent.

\section{Heydar Aliyev's Presidency and Its Nation-Building Agenda}

The replacement of the PFG by Aliyev signified a shift in the nation-building agenda and introduced a new discourse on how to construct national identity. The conceptualization of the government understanding of national identity took its roots from the very terminology of the Soviet period. Azerbaijani people had acquired three different names (Tatars or Muslims, Turks, and Azerbaijanis) in the 20th century (Altstadt 1992). Aliyev's government of Azerbaijan preferred the use of Azerbaijani for both the language and citizenship. It has taken cautious measures against the intensive emphasis on Turkishness of the PFG's discourse and some separatist movements, such as the Lezgins and Talyshs in 1993 and 1994.

The Azerbaijani Constitution, adopted in 1995, calls the people of Azerbaijan Azerbaijanis (Azerbaycanli) and their language the language of Azerbaijan (Azerbaycan dili) (Republic of Azer. Const. art. 21). Thus, Azerbaijani became the official name for the national identity, citizenship, and language. The main argument behind this was that the term covers all the peoples living in Azerbaijan regardless of their ethnicity and left no room for disturbances among the ethnic minorities. ${ }^{14}$ Aliyev's regime then eased the possible tensions between ethnic groups while shifting the emphasis on Turkism of the PFG to Azerbaijanism. Tabachnik states that he "carefully crafted territorial nationalism policy of 'Azerbaijanism' on basing the nation of the territory of state" (2019, 227). In this sense, Azerbaijanism was conceived as a civic rather than ethnically defined national identity. As Siroky and Mahmudlu state, "Aliyev sought to create -Azerbaijanism- - an overarching identity that includes all citizens, regardless of ethnicity or religion-as a response to the ethnic separatism of the early 1990s and the continuing threat of ethnic conflict" $(2016,99)$.

Azerbaijanism was thought of as "a project for the unification of people" considering that "people living in the territory of Azerbaijan are Azerbaijanis." ${ }^{15}$ According to the ruling New Azerbaijan Party's program, Azerbaijanism and patriotism are its main principles. It is stated that it considers "all Azerbaijani citizens living in the country and outside of it, who obey Azerbaijani State and its laws, irrespective of their language, ethnic, and social origins, as Azerbaijani people and considers Azerbaijan as the common, indivisible motherland and native country" and the party "binds defense of Azerbaijani people's national and moral values, traditions, national moral mentality, language, and religion by a single Azerbaijani state" (New Azerbaijan Party 1999).

Representatives of the ruling party argued that the emphasis on Turkism would lead to separatist movements; therefore, "national ideology should be Azerbaijanism" as "Turks, Lezgins, Talyshs, Russians and even Armenians living in Azerbaijan are Azerbaijanis." 16 Azerbaijanism was not only thought of as a basis for nationhood but also was a facilitating tool for the consolidation of statehood where stability was the main concern. In terms of majority-minorities relations, there was no conflict after 1994. ${ }^{17}$ Although it is argued that Lezgins ${ }^{18}$ would be the "next candidates for autonomous-territorial status" (Swietochowski 1999, 421), the possible emergence of separatist movements was found less likely to occur by the interviewees who argued "they are already Azerbaijanified" in the sense that they all speak the Azerbaijani language, are well integrated in society, and agree with the naming of Azerbaijan. ${ }^{19}$ Thus, the government discourse on nationbuilding did not make any distinction between the majority and minorities, unifying them under the name Azerbaijani. The inclusiveness implies that ethnic minorities are less likely to cause further problems for the consolidation of nation- and state-building, particularly in the early years of the post-independence period when the territorial integrity had been violated. Aliyev's government undertook considerable steps to consolidate nationhood under the rubric of Azerbaijani after 
dealing with the upheavals by Lezgins and Talyshs. Especially in his last years in power, he also fostered the widespread usage of the native language and acquired important achievements in the protection and development of the language as a symbol of national identity.

The opposition to the Aliyev's government was distinctive with its continuing emphasis on Turkism. For the opposition, the name of the language is Turkish (Türk Dili) and the national identity is Turkish (Türk). They did not object to the usage of Azerbaijani Turkish and Azerbaijani Turks (Azerbaycan Türkü). Thus, it is this Turkishness that constitutes the basis of the opposition's discourse. The year of 1995 was critical in that respect and was marked by an ongoing debate on how to name the language and the national identity (Haciyev 1992; Tahirzade 1995; Gamber 1996; Vahabzade 1996). In 1995 parliamentary elections and a referendum on the constitution were held. The government's preference for Azerbaijani further demonstrated the opposition's discourse.

After the official recognition of Azerbaijani as a name of the identity and the language, the Azerbaijan Popular Front Party declared that, "in December 1992, Milli Mejlis (parliament), considering the historical past, the memory of the oral and written language of its people, as well as taking into account numerous academic-historical facts and the principle of national statehood, passed a decree on the official language of Azerbaijan. With this decision historical justice was reconsolidated and the official language was named Turkish language, as it had been in the period of the National Democratic Republic of Azerbaijan." ${ }^{20}$ Similarly, the chair of the Musavat Party argued, "the name of our language has been Turkish throughout history. They [ethnic minorities] could not be jealous of the majority's right to name its own language” (Gamber 1996, 7).

In the opposition agenda, nationalism was defined as "loving the nation, being ready to make sacrifice in the name of nation and being faithful to the nation's ability to rule itself." (Müsavat Partiyasının Proqram ve Nizamnamesi 1997, 4). In this nationhood project, Turkism was referred to as "national self-consciousness" and as "a basis of the multifaceted closeness and collaboration of the Turkic peoples and states" (5). The opposition rejects the usage of Azerbaijani to describe national identity, arguing that Azerbaijan is the name of territory where "Turks live" (Rustemxanl1 1998, 64). One politically active linguist disagreed with his colleagues who preferred the term Azerbaijani, arguing, "All your enemies call you 'Turks,' and you are now saying that 'No we are not'. How will you explain this injustice to your grandchildren? How will you look at their face when they will ask you who they really are?" ${ }^{21}$ Here he drew attention to the fact that Azerbaijanis living in Iran call themselves as Turks and are called the same by Persians. Similarly, Armenians frequently call Azerbaijanis Turks (Abrahamian 2001; Dragadze 1989, 56; Laitin and Suny 1999, 147).

The opposition included Azerbaijanism in its nation-building agenda in a distinctive way. It captured this term not as a basis for defining national identity but as complementary to Turkism. Azerbaijanism was also considered to be related to the idea of citizenship rather than national identity. For the Musavat Party, it was defined as "[the] Azerbaijani patriotism loyal to independence, unitarism and unity and to the ideals of freedom and independence" (Müsavat Partiyasinın Proqramı ve Nizamnamesi 1997, 5), whereas Turkism refers to "the national self-consciousness" and was considered as "the basis of rapprochement and cooperation among Turkish peoples and states" (5). The ideology of the Party, Musavatçılıq was defined as "the Azerbaijani patriotism loyal to national civilization, internalizing international values tied with the ideals of freedom, republic, and stability" (5). The Azerbaijan Popular Front Party defined Azerbaijanism as "the moral, political and national unity deriving from people's consciousness of the feeling of an Azerbaijani motherland and an Azerbaijani state. This is to feel and to understand that Azerbaijan is the only motherland, to recognize the Azerbaijani state as one's own and to feel as a member of the Azerbaijani people" (Azerbaijan Popular Front Party Programme 1999, 3). The complementary nature of Azerbaijanism showed itself in the principles of national statehood in Azerbaijan, the territorial integrity of the country, the defense of country, and the protection of the rights of ethnicnational minorities. In their understanding, “Azerbaijanism completes Turkism with its idea of protecting of Azerbaijani national statehood, indivisibility of the state and the protection of national 
ethnic minorities" (Nasibzade 1998, 6). Therefore, “Azerbaijanism consists of the idea of independence, unity, and totality, but it is not the national identity, only a part of it" (Ibrahimli 1998, 52).

In the opposition discourse the status of ethnic groups was seen as part of the citizenship agenda rather than the nation-building agenda. In this respect, both government and opposition have an understanding of civic nationalism for state-building. They do not exclude national minorities and openly declared that they would not be discriminated against on the basis of ethnicity or religion. They do not intend to create a homogenous nation and state but rather a state where there is a distinction between the majority and minority.

The opposition's discourse on majority and minority relations is very significant. They argue that Azerbaijani Turks are the dominant majority, which encompasses the characteristics of a nation, while the rest are ethnic minorities. This view has two implications. On the one hand, it is in the national interest of the Azerbaijani Turks "to protect its statehood, and create its political, economic, and ideological basis" (Gezenferoglu 2000, 297). For the opposition it is the role of the majority (or those who represent the majority) to form the nation and define the ideology of the would-be nation while taking into account the status of the ethnic minorities living in the territory. Thus, they argue that it is still the majority's right and duty to protect the rights of the ethnic and religious minorities living in a country with "a state policy which is determined by Turkic identity, Turkic character, and a Turkic mission. This policy has to create opportunities for other ethnic and religious civilizations to live under the roof of this state" (298-299).

To conclude, in the opposition's agenda, "being nationalist" was used in the sense of loving the nation and the state, propagating the revival of the national memory, defining integrity and solidarity on the basis of national identity rather than on regional identity, and clientelistic networks or clan based politics. Although the opposition defines its nation-building agenda in accordance with the majority's dominance, it is remarkable that they do not discriminate on the basis of the ethnic differences between majority and minorities. After the overthrow of the PFG, the project of nationhood of Aliyev's government shifted its emphasis to Azerbaijanism in order to create so-called stability not only in state affairs and administration but also in nation-building. Stability was to be achieved with cohesiveness among all ethnic groups living in the territory.

\section{Ilham Aliyev's Presidency and Contemporary Interpretations of National and Citizenship Identities}

Ilham Aliyev, who came to power in 2003, inherited the notion of national identity and fostered construction of citizenship identity. He also promoted the notion of Azerbaijaniness, yet a slight change in his term in the office is also remarkable. The notion of citizenship has been reconceptualized through the incorporation of multiculturalism and tolerance with a very strong emphasis on secularism. This discourse has been particularly promoted before and during the international events hosted in Baku (Valiyev 2016; Rojo-Labaien 2018; Ismayilov 2012; Siroky and Mahmudlu 2016).

The above-mentioned conflicting views on naming national identity in the early years of independence do not occupy the intellectual and public debate in Azerbaijan. Azerbaijaniness is well consolidated both as citizenship and national identity acknowledging a strong ethnic component, that is the Turkish identity. It can be argued that the ethnic dimension reminded and incorporated by the PFA is now more consciously embraced, yet it does not override or underestimate Azerbaijaniness.

In the existing context, a very strong emphasis on the independent statehood is being made with reference to citizenship identity. The territorial integrity and the resolution of the Karabakh conflict are of utmost importance for the preservation of independent and consolidated statehood. PreSoviet experience of statehood has been highly valued, and the Azerbaijani government celebrated 100th Anniversary of the establishment of the Azerbaijani Democratic Republic and glorified the previous statehood experience. The discourse of modernization and secularism, which was essential 
to the ADR's political and intellectual elite, has been celebrated, underlining as the main ideological sources of the current Azerbaijani identity. The Soviet experience of peaceful coexistence and cohabitation of ethnic and religious groups provided a basis for the promotion of multiculturalism and tolerance in Azerbaijan. This is not only a discourse on the acknowledgement of cultural diversity but also a very strong emphasis on the preservation and promotion of secularism.

\section{Defining "Friend and Foe": The Impact of Foreign Countries on the Perception of National Identity}

In the post-Soviet period, the impact of the relations with Russia, Iran, and Turkey on nationbuilding was very significant. The conduct of foreign policy toward these states inspired the PFG's agendas of state- and nation-building in many ways and constitute the main pillars of both Heydar and Ilham Aliyev's governments. New state-building in the early years of independence also required a new foreign policy with strong emphasis on the definition of friends and foes. The PFG was characterized as pro-Turkey, pro-West, anti-Iran, and anti-Russia, whereas Heydar Aliyev conducted a more balanced policy toward the neighbors (Cornell 2011; Hunter 1997; Swietochowski 1999). The impact of the relations with Armenia, Russia, Iran, and Turkey on nation- and state-building was very significant. New state-building also required a new foreign policy. In this respect the agenda of state-building and the definition of friends and foes were also interrelated to nation-building.

Turkey has a special prestige in the country because of the cultural, ethnic, and linguistic similarities. The country is considered as the best ally and ultimate friend of Azerbaijan by both the government and the opposition. The fact that Turkey was the first country to recognize Azerbaijan's independence, as well as her unconditional support for Azerbaijan on the Karabakh problem and the refusal of building diplomatic ties with Armenia, created very close ties of friendship and a strategic partnership. The motto of "one nation two states" frequently referred to by all presidents and politicians of both countries contributes to this extensively peculiar relationship, which also has a very strong basis in both Azerbaijani and Turkish public opinions. ${ }^{22}$

Russia's impact on nation-state building can be seen in the emphasis on the territorial integrity and on the protection of independence. The PFG considered Russia and Armenia as threats to the state's independence and territorial integrity. Russia is considered as a main threat for the independence and security of statehood because it did not decline "its imperialistic ambition." 23 It symbolizes the past, hegemony, and dominance, as well as the authoritarian system. One politician said, "Once Nerimanov said that Azerbaijan's happiness is tied with its union with Russia. I argue the antithesis. Azerbaijan's happiness depends on its purification from Russia." 24 Additionally, Russia's potential to provoke national ethnic minorities was expressed. ${ }^{25}$ Besides the Karabakh problem, Armenian and Russian military alliance is considered as a threat to territorial integrity. Moreover, Armenia and Russia have an impact on nationhood within the territory, since they constitute Others of the Azerbaijani nation in the pre-independence period and its aftermath.

Iran, on the other hand, has some historical legacies in Azerbaijani culture (Hunter 1997; Swietochowski 1994a, 1994b). Both countries are Shi'a Muslims, and the declaration of independence might have led to an opening up of Iran to its religious brothers. However, the PFG declared its will to remain a secular democratic state, and the elite was secular minded (Swietochowski 1999, 423). The PFG also gave a particular emphasis to the development of relationships between Iranian (Southern) Azerbaijan and the Republic of Azerbaijan, propagating for the protection of the cultural rights of Azerbaijanis in Iran in its project of nationhood beyond the boundaries. The fact that the Azerbaijani territory was divided into two (one part remaining in Russia and the other in Iran by the Turkmancay Treaty signed in 1828) widely affected the nationalist inspirations of the intellectual elite of Azerbaijan in 1970s and 1980s (Nissman 1984; Swietochowski 1995). The division was referred to as "Azerbaijanis are divided between two lands" as a "result of historical injustice," "misfortune of history," and "the rivalry between the big powers." 26 The idea of a Unified 
Azerbaijan (Butov Azerbaycan) was launched by Elchibey, aiming to unify both people and territory. However, the implication of living under different rules and (perhaps more importantly) under different cultures caused a real alienation among Azerbaijanis. When the interaction between two groups increased, different cultural, religious, and linguistic practices revealed variances. Iranian Azerbaijanis criticized those in the Azerbaijani SSR for being "Russified," "losing their language," and "forgetting their religion," whereas the other side occasionally referred to them as "backward" and "fundamentalist." 27

Heydar Aliyev's government, however, took cautious measures against this policy, arguing that such ideas could harm the Azerbaijani-Iranian relationship and that the status of ethnic Azerbaijanis was an internal affair of Iran, and so he avoided intervening. One can argue that discourses of national identity and nation-building are also reflected in the foreign policy making of Azerbaijan and the impact of neighboring countries are also remarkable. One cannot ignore the role that common ethnic, religious, and cultural backgrounds, along with a shared historical and political heritage, play in defining friends and foes. Yet the political leaderships of the postindependence period made a conscious choice in accordance with their preferences in their discourses of national identity. This is constructing, promoting, and strengthening extremely good ties with Turkey; preserving distance with Iran; preventing its particularly religious influence when necessary; and conducting a cautious and balanced policy toward Russia bearing in mind its support to Armenia and its potential for intervention as in the cases of Georgia and Ukraine. Such choices in defining foreign policy priorities are also informed by the strong emphasis on the independence and consolidation of the statehood by the respondents.

\section{The Main Challenge to Nation-Building in Post-Soviet Azerbaijan: The Karabakh Conflict}

The discourses of national identity and nation-building have been informed by the political and cultural characteristics of the country and of the region. In the political transformation of Azerbaijan, the Karabakh conflict burdened the processes of democratization, nation-building, and state-building.

The Karabakh conflict has a decisive role in the process of nation-building. It permeated the redefinition of national identity by redefining others and fostered the national independence movement. It is also an integral part of state-building, since the territorial integrity of the country is violated. The Karabagh issue is also an integral part of the democratization process as both defeat and success in handling the issue was and is always at the center stage of opposition policies in its struggle against government. Initially a secessionist movement, the conflict became an interstate war that had a significant impact both on Armenian and Azerbaijani political transformations. The war resulted in an estimated 25,000 dead (Macfarlane and Minear 1997, 1), and the number of estimated casualties are 7,000-8,000 on the Armenian side and 20,000-22,000 on the Azerbaijani side (Panossian 2001).

The Karabakh problem has a considerable impact on both state-building and nation-building. In Armenia and Azerbaijan, the issue of Karabagh was the main impulse behind the formation of the independence movements. Armenians were content to be a part of the Soviet Union, considering it as a guarantee against "Turkish aggression" (Dudwick 1997, 77). However, they supported their compatriots in Azerbaijan when the latter asked for secession (78). The Karabakh Committee was initiated by the Armenians of the NKAO and became a unified movement with their compatriots in Armenia under the name of the Armenian National Movement (Smith 1991, 211). Around ideas of "psychological protection against the 'Turkic threat,' in part by identifying the Azerbaijanis indiscriminately and erroneously with the Turkish people" (Smith et al. 1998, 50), the restoration of a "non-territorial nationalism" (Suny 1990, 14), and the stimulation of the right of self-determination (Rutland 1994, 842), the NagornoKarabakh Armenians declared their sovereignty in spring 1990 and occupied approximately $20 \%$ of Azerbaijani territory by the autumn of 1993 . 
For the Azerbaijanis, it is considered as a historical territory of Azerbaijan where "they have been good hosts to their Armenian neighbor-guest" (Altstadt 1988, 74). They regard Nagorno Karabakh as an integral part of their history and territory where Armenians unjustly occupy $20 \%$ of Azerbaijani territory, resulting in more than one million refugees and internally displaced people. These people have been living in drastically severe conditions for the last decades. Azerbaijan without Karabakh is unthinkable. Azerbaijanis consider the conflict as affecting their territorial integrity and challenging the inviolability of the frontiers.

In Azerbaijan, Karabakh's significance is tied to all three processes of political transformation. First and foremost, the Karabakh conflict paved the way for the creation of Others, that is, Armenians and Russians. Second, it constituted the main incentive behind the national movement, enabling the creation of national identity. The loss of territory has lessened the nation's and citizens' faith in themselves. The defeat in Karabakh also provoked the psychology of defeat, since the Azerbaijanis felt threatened and unprotected by the unjust occupation of territory. It also decreased hopes to get the territory back due to the status quo achieved by the cease fire. This has led in a lessening of political activism through a national awakening that previously paved the way for independence.

Last, the conflict also has a significance for the process of state-building. Besides being the main stimulus of the independence movement, Karabakh is the sacred and untouchable signifier of territorial integrity, which is the basis for statehood, and it consolidates the national identity that included both Azerbaijanism and Turkism. As of 2020, both the Azerbaijani government and society strongly underline the fact that a surrender of any form is not acceptable and that the occupied territories should be freed through a peaceful resolution.

\section{Conclusion}

In the early years of the political transformation in Azerbaijan, debates on how to construct the nation took place in relation to state-building and democratization. It constituted one of the primary dichotomies between government and opposition and their projects for an independent and democratic statehood. The Karabakh conflict remains a major problem for the consolidation of democracy and state-building. Since the official constitutional recognition of Azerbaijani as the name of the identity and language, the intellectual and political debate on "who we really are" and "what the components of the nation are" became silent issues embedded in a new discourse of multiculturalism and tolerance, which are well accommodated. Yet both the nation-building project and process would only be completed by the return of the occupied territories. Previous experience of cohabitation with ethnic and religious minorities and a strong emphasis on multiculturalism and tolerance have the potential to contribute to the consolidation of state-building after territorial integrity is secured.

Acknowledgement. I would like to thank Meryem Orujlu, Farda Asadov, and Zana Çitak for their invaluable comments and suggestions in the writing up of this article. I am extremely grateful to all of my respondents in Baku who shared their views with me.

Disclosure. Author has nothing to disclose.

\section{Notes}

1 Representative of the PFA elite, July 2018, Baku, interviewed by the author.

2 These were the main issues frequently expressed and strongly emphasized by the interviewees.

3 He referred to the flag of the First Republic of Azerbaijan. It is a three colored flag: blue (symbolising Turkism), red (for modernization) and green (for Islam).

4 A historian and member of opposition elite, July 2000, Baku, interviewed by the author.

5 High ranked party representative of the PFA, November 2000, Baku, interviewed by the author. 
6 Representative of the Musavat Party, December 2000, Baku, interviewed by the author.

7 This statement has been frequently expressed by the respondents during the fieldworks, August 1998, December 2016, April 2017, Baku.

8 Scholars, journalists and experts, 2016-2017, Baku, interviewed by the author.

9 Experts, December 2019, Baku, interviewed by the author.

10 The slogan'Turkism, Modernization, and Islamism' is the essence of the ideology known as Musavatism (Musavatcilik). For a detailed discussion, see Altstadt (1992) and Swietochowski (1995).

11 Ebulfez Elchibey, Chair of the Azerbaijan Popular Front Party, July 1998, Baku, interviewed by the author.

12 In Azerbaijan, until 1937, people of Azerbaijan were called Turks. As a result of the Stalinist policies of Sovietization, the majority who used to be called Turks became Azerbaijanis whereas the other ethnic minorities living in the Azerbaijan SSR kept their names. See Altstadt (1992) and Ergun (2010).

13 Ebulfez Elchibey, July 1998, Baku, interviewed by the author.

14 Azerbaijanis constitute $91.6 \%$ of the population. There are ethnic minorities living in the territory. These are Lezgins (2\%), Talyshs (1.3\%), Avars, Turks, Tatars, Georgians, Armenians (1.3\%), Russians (1.3\%) and Kurds. The majority of population is Muslims (95\%). $85 \%$ of the Muslim population is Shi'a Muslims whereas 15\% is Sunnis. Religious minorities include Russian Orthodox, Armenian Orthodox, and Jews. See The State Statistical Committee of the Republic of Azerbaijan (2020).

15 Government elites, July 2000, Baku, interviewed by the author.

16 Government elites, July 2000, Baku, interviewed by the author.

17 For a detailed discussion of ethnic minorities and majority-minority relations in Azerbaijan, see Cavadov (2000), and Siroky and Mahmudlu (2016).

18 Lezgins are Caucasian people living in Southern Dagistan and Northern Azerbaijan. In Azerbaijan they mainly live in the northern rayons of Qusar, Quba, Sheki, Shamakhi, and Khachmaz (Matveeva and McCartney 1998, 217).

19 Government elite, July 2000, Baku, interviewed by the author.

20 Popular Front of Azerbaijan $(1996,8)$.

21 Turkologist, April 1999, Baku, interviewed by the author.

22 For a thorough analysis of bilateral relations, see Ismayilov and Graham (2016), Veliyev (2020), and Ergun (2007).

23 Hikmet Haji-zadeh, September 1998, Baku, interviewed by the author.

24 Politician from opposition, August, 2000, Baku, interviewed by the author.

25 Historian, July 2000, Baku, interviewed by the author.

26 These are the views expressed by the respondents during fieldwork in Azerbaijan July 2000, Baku.

27 These are the views expressed by the respondent during fieldwork in Azerbaijan, July 2000, Baku.

\section{References}

Abrahamian, Levon Hm. 2001. “Civil Society Born in the Square: the Karabagh Movement in Perspective.” In The Making of Nagorno-Karabagh, edited by Levon Chorbajian, 116-134. New York: Palgrave.

Akiner, Shireen. 1997. "Melting Pot, Salad Bowl-Cauldron? Manipulation and Mobilisation of Ethnic and Religious Identities in Central Asia.” Ethnic and Racial Studies 20 (2): 362-398.

Altstadt, Audrey L. 1986. “Azerbaijani Turks' Response To Russian Conquest.” Studies in Comparative Communism 19:(3-4): 267-286.

Altstadt, Audrey L. 1988. "Nagorno-Karabagh-'Apple of Discord' in the Azerbaijan SSR.” Central Asian Survey 7 (4): 63-78.

Altstadt, Audrey L. 1992. The Azerbaijani Turks: Power and Identity Under the Soviet Rule. Stanford, CA: Hoover Institution Press. 
Altstadt, Audrey L. 2017. Frustrated Democracy in Post-Soviet Azerbaijan. Washington D.C.: Woodrow Wilson Center Press. Azerbaijan Popular Front Party Programme. 1999. Baku.

Azerbaycan. 1992a. "The Presidential Decree on the Protection of the Rights and Liberties of National Minorities, Less Populated and Ethnic Groups and State Assistance for the Development of their Language and Civilisation." November $12,1992$.

Azerbaycan. 1992b. “The Presidential Decree on the Official Language of the Republic of Azerbaijan.” December $22,1992$.

Balayev, Aydın, and Rasim Mirze. 2000. 20 Yanvar Hadiseleri, Senedler, Movgeler, Serhler. Baki: Casioglu.

Bremmer, Ian, and Ray Taras. 1997. New States, New Politics: Building the Post-Soviet Nations. Cambridge: Cambridge University Press.

Broers, Laurence. 2019. Armenia and Azerbaijan: Anatomy of a Rivalry. Edinburgh: Edinburgh University Press.

Brubaker, Rogers. 1996. Nationalism Reframed. Cambridge: Cambridge University Press.

Buttino, Marco. 1993. In a Collapsing Empire, Underdevelopment, Ethnic Conflict and Nationalisms in the Soviet Union. Milano: Fondazione Giagacomo Feltrinelli.

Cavadov, Qəmərşah Cəllad. 2000. Azerbaycanin Az Sayili Halqlari ve Milli Azliqlari. Baki: Elm Neshriyyati.

Chorbajian, Levon. 2000. The Making of Nagorno-Karabagh. London: Palgrave.

Cornell, Svante E. 2011. Azerbaijan since Independence. USA: M.E. Sharp.

Cornell, Svante E., Halil Karaveli, and Boris Agajanov. 2016. Azerbaijan's Formula: Secular Governance and Civic Nationhood, Silk Road Paper. Central Asia-Caucasus Institute \& Silk Road Studies Program.

De Waal, Thomas. 2013. Black Garden: Armenia and Azerbaijan Through Peace and War. New York: New York University Press.

Diuk, Nadia, and Adrian Karatnycky. 1993. New Nations Rising: The Fall of the Soviets and the Challenge of Independence. New York: John Wiley \& Sons.

Dragadze, Tamara. 1989. “The Armenian-Azerbaijani Conflict.” Third World Quarterly 11 (1): 55-71.

Dudwick, Nora. 1997. "Political Transformations in the Post-Communist Armenia." In Conflict, Cleavage, and Change in Central Asia and the Caucasus, edited by Karen Dawisha and Bruce Parrott, 69-109. Cambridge: Cambridge University Press.

Elchibey, Ebülfez. 1992. Bu Menim Taleyimdir. Baku: Genclik.

Elchibey, Ebülfez. 1998. Butov Azerbaycan Yolunda. Ankara: Ecdad Publications.

Ergun, Ayça. 2007. “Türkiye-Azerbaycan İlişkileri.” In Türkiye’nin Avrasya Macerası, edited by Mustafa Aydın, 241-268. Ankara: Nobel Yayınevi.

Ergun, Ayça 2010. “Politics of Romanization in Azerbaijan (1921-1992)." Journal of Royal Asiatic Society 20 (1): $33-48$.

Ergun, Ayça, and Zana Çitak. 2020. "Secularism and National Identity in Azerbaijan.” Journal of Church and State 62 (3): $464-483$.

Gamber, Isa. 1996. ”Dilimizin Adi Kadim Zamandan Beri Turk Dilidir.” Azerbaycan 45 (307): 7-8.

Garagozov, Rauf. 2012. "Do Woes Unite Foes? Interplay of Narratives, Memory, Emotions and Attitudes in the Karabakh Conflict." Dynamics of Asymmetric Conflict 5 (12): 116-137.

Gezenferoglu, Fazil. 2000. Olumden Sonraki Dirilis. Baku: Azerbaycan Milli Demokratya Fondu.

Guliyev, Farid. 2019. "Discursive Closure: Political Parties and the (Ir)relevance of Ideology in Azerbaijan." Southeast European and Black Sea Studies 19 (2): 243-268.

Goltz, Thomas. 1998. Azerbaijan Diary. New York: M.E. Sharp.

Hajda, Lubomyr, and Mark Beissinger. 1990. The Nationalities Factor in Soviet Politics and Society. Boulder: Westview Press.

Haciyev, Hikmet. 1992. "Dilimizin Adi ve Perisanligin Sebebi.” Azerbaycan, December 29, 1992.

Hatcher Lynley. 2008. "Script Change in Azerbaijan: Acts of Identity.” International Journal of Sociology of Language 192: $105-116$.

Heyat, Farideh. 2006. “Globalization and Changing Gender Norms in Azerbaijan.” International Feminist Journal of Politics 8 (3): 394-412.

Hobsbawm, Eric. 1983. The Invention of Tradition. Cambridge: Cambridge University Press.

Hunter, Shiren T. 1997. “Azerbaijan: Searching for New Neighbors.” In New States, New Politics: Building the Post-Soviet Nations, edited by Ian Bremmer and Ray Taras, 437-470. Cambridge: Cambridge University Press.

Ibrahimli, Xaleddin. 1998. “Azerbaycancılı̆̆ın Düneni ve Çağdas Interpretasyası.” In Azerbaycan'ın Türkçülük ve Azerbaycancilıq Problemleri, edited by Xaleddin İbrahimli, 48-54. Baku: Elm.

Ismayilov, Murad. 2012. "State, Identity and the Politics of Music: Eurovision and Nation-Building in Azerbaijan." Nationalities Papers 40 (6): 833-851.

Ismayilov, Murad, and Norman A. Graham, eds. 2016. Turkish-Azerbaijani Relations. Oxon: Routledge.

Lemercier-Quelquejay, Chantal. 1984. "Islam and Identity in Azerbaijan." Central Asian Survey 3 (2): 29-55.

Laitin, David D., Suny, Ronald G. 1999. “Armenia and Azerbaijan: Thinking a Way Out of Karabakh.” Middle East Policy 7 (1): $145-176$.

Lapidus, Gail, Victor Zaslavsky, and Philip Goldman. 1992. From Union to Commonwealth. Cambridge: Cambridge University Press. 
Macfarlane, Neil, and Larry Minear. 1997. Humanitarian Action and Politics: The Case of Nagorno-Karabakh. Occasional Paper 25. Providence: Watson Institute.

Mahmudlu, Ceyhan. 2017. “Theorizing Nation Building in Azerbaijan.” In "Azerbaijani” and Beyond, edited by Aliaga Mammadli, Adeline Braux, and Ceyhun Mahmudlu, 124-150. Berlin: Verlag Dr. Köster.

Matveeva, Anna, and Clem McCartney. 1998. "Policy Responses to an Ethnic Community Division: Lezgins in Azerbaijan." International Journal on Minority and Group Rights 5 (3): 213-252.

Müsavat Partiyasının Proqramı ve Nizamnamesi. 1997. Baku.

Nasibzade Nasib. 1998. “Konferansın Açılış Nitqi.” In Azerbaycan'ın Türkçülük ve Azerbaycancılıq Problemleri, edited by Xaleddin İbrahimli, 4-12. Baku: Elm.

Nerimanoglu, Kamil Veli. 1992. Ebulfez Eli Elci Bey. Istanbul: Turk Dunyasi Arastirmalari Vakfi.

New Azerbaijan Party. 1999. "The Program of the New Azerbaijan Party Adopted in the First Congress of the New Azerbaijan Party on December 21, 1999.” New Azerbaijan Party, December 21, 1999. http://www.yap.org.az/en/view/pages/9. (Accessed June 20, 2020.)

Nissman, David. 1984. “The Origin and Development of the Literature of 'Longing' in Azerbaijan." Journal of Turkish Studies 8: 199-207.

Panossian, Razmik. 2001. “The Irony of Nagorno-Karabakh: Formal Institutions versus Informal Politics.” Regional and Federal Studies 11 (3): 143-164.

Papazian, Lalig. 2001. “A People's Will: Armenian Irredentism over Nagorno-Karabagh.” In The Making of NagornoKarabagh, edited by Levon Chorbajian, 54-94. London: Palgrave.

Popular Front of Azerbaijan. 1996. “Azerbaycan Halk Cephesi Partisinin Görüşü: Turk Dilini Savunmaya Devam Edeceğiz.” Azerbaycan 45 (307): 8.

Rojo-Labaien, Ekain. 2018. “The Baku 2015 European Games as a National Milestone of post-Soviet Azerbaijan.” Nationalities Papers 46 (6): 1101-1113.

Rustemxanlı, Sabir. 1998. “Ideologyamizin Temeli Tarihtedir.” In Azerbaycanda Türkçülük ve Azerbaycancılıq Problemleri, edited by Xaleddin İbrahimli, 60-70. Baku: Elm.

Resulzade, Muhammed A. 1989. Asrımızın Sivayavuş’u. Azerbaycan Kültür Derneği Yayınları 39. Ankara: Azerbaycan Kültür Derneği Yayınları.

Rutland, Peter. 1994. "Democracy and Nationalism in Armenia." Europe-Asia Studies 46 (3): 839-861.

Saroyan, Mark. 1989. "Beyond the Nation-State: Culture and Ethnic Politics in Soviet Transcaucasia." Soviet Union, Union Sovietique 15 (2-3): 219-244.

Siroky, David S., and Ceyhun Mahmudlu. 2016. "E Pluribus Unum? Ethnicity, Islam and Construction of Identity in Azerbaijan." Problems of Post-Communism 63 (2): 94-107.

Smith, Graham Edward. 1991. "The State, Nationalism and the Nationalities Question in the Soviet Republics.” In Perestroika The Historical Perspective, edited by Catharine Merridale and Chris Ward, 202-216. London: Edward Arnold.

Smith, Graham, Vivien Law, Andrew Wilson, Annette Bohr, and Edward Allworth. 1998. Nation-Building in the Post-Soviet Borderlands. Cambridge: Cambridge University Press.

Sultanova, Shahla. 2014. "Challenging the Aliyev Regime: Political Opposition in Azerbaijan.” Demokratizatsya 22 (1): 15-37.

Suny, Ronald. 1990. "The Revenge of the Past: Socialism and Ethnic Conflict in Transcaucasia.” New Left Review 184:5-37.

Swietochowski, Tadeusz. 1994a. "Azerbaijan: A Borderland at the Crossroads of History' in Starr." In The Legacy of History in Russia and the New States of Eurasia, edited by Frederick S. Starr, 277-299. New York: M.E. Sharp.

Swietochowski, Tadeusz. 1994b. “Azerbaijan's Triangular Relationship: The Land Between Russia, Turkey and Iran.” In The New Geopolitics of Central Asia and Its Borderlands, edited by Ali Banuazizi and Myron Weiner, 118-135. London: I.B. Tauris.

Swietochowski, Tadeusz. 1995. Russia and Azerbaijan: A Borderland in Transition. New York: Columbia University Press.

Swietochowski, Tadeusz. 1999. “Azerbaijan: Perspectives from the Crossroads." Central Asian Survey 18 (4): 419-434.

Tabachnik, Maxim. 2019. "Defining the Nation in Russia's Buffer Zone: The Politics of Citizenship by Birth on Territory (jus soli) in Moldova, Azerbaijan and Georgia.” Post-Soviet Affairs 35 (3): 223-239.

Tahirzade, Adalet. 1996. “Türk Dili: Ikinci Tehgir Astanasında." Yeni Musavat, June 23, 1996.

Tahirzade, Adalet. 1997. Meydan Dort Il Dort Ay. Baku : Ay-Ulduz Neşriyatı.

Tahirzade, Adalet. 1999. Elcibeyle 13 Saat Uz-Uze. Baku : Tanitim Gazetinin Neşri.

Tishkov, Valery. 1997. Ethnicity, Nationalism and Conflict in and after the Soviet Union. London : Sage.

The State Statistical Committee of the Republic of Azerbaijan. 2020. “Population.” Statistical Yearbook of Azerbaijan 2020. Last updated October 1, 2020. https://www.stat.gov.az/source/demoqraphy/?lang=en. (Accessed April 15, 2020.)

Tohidi, Nayereh. 1997. "The Intersection of Gender, Ethnicity and Islam in Soviet and Post Soviet Azerbaijan." Nationalities Papers 25 (1): 147-197.

Uzer, Umut. 2012. "Nagorno-Karabakh in Regional and World Politics: A Case Study for Nationalism, Realism and Ethnic Conflict." Journal of Muslim Minority Affairs 32 (2 ): 245-252.

Vahabzade, Bahtiyar. 1996. “Dilimiz Azerbaycan Türkçesi Milliyetimiz de Azerbaycan Türküdür.” Azerbaycan 45 (307 ): 9-12.

Valiyev, Anar. 2005. "Under Construction and Highly Contested: Islam in Post-Soviet Caucasus." Middle East Review of International Affairs 9 (4): 1-12. 


\section{Ayça Ergun}

Valiyev, Anar. 2016. "First European Olympic Games in Baku: New Articulation of Azerbaijani Identity.” Mega Events in PostSoviet Eurasia, edited by Andrey Makarychev and Alexandra Yatsyk, 131-149. Michigan : Palgrave MacMillan US.

Veliyev, Cavid. 2020. Azerbaycan-Türkiye Stratejik Ortaklı̆̆ı. İstanbul Ötüken.

Yllmaz, Harun. 2013. "The Soviet Union and the Construction of Azerbaijani National Identity in the 1930s." Iranian Studies 46 (4): 511-533.

Zaslavsky, Victor. 1992. "Nationalism and Democratic Transition in Post-Soviet Societies.” Daedalus 121 (2): 97-121.

Zürcher, Christian. 2007. The Post-Soviet Wars: Rebellion, Ethnic Conflict and Nationhood in the Caucasus. New York: New York University Press.

Cite this article: Ergun, A. 2022. Citizenship, National Identity, and Nation-Building in Azerbaijan: Between the Legacy of the Past and the Spirit of Independence. Nationalities Papers 50: 813-830, doi:10.1017/nps.2020.81 